\title{
Pulmonary embolism by a foreign body that migrated in the inferior vena cava during lumbar spine surgery
}

\author{
Noritsugu Naito, ${ }^{1}$ Masaru Abe, ${ }^{2}$ Motoji Fukasawa, ${ }^{3}$ Akihiko Takeshi ${ }^{2}$
}

${ }^{1}$ Gunma Prefectural

Cardiovascular Center, Gunma, Japan

${ }^{2}$ Kameda Medical Center, Chiba, Japan

${ }^{3}$ Kawasaki Saiwai Hospital, Kanagawa, Japan

\section{Correspondence to}

Dr Noritsugu Naito,

nori.naito@gmail.com

Accepted 8 September 2014

CrossMark

To cite: Naito N, Abe $\mathrm{M}$ Fukasawa $\mathrm{M}$, et al. BMJ Case Rep Published online: [please include Day Month Year] doi:10.1136/bcr-2014205423

\section{DESCRIPTION}

A 72-year-old man was referred to our department for evaluation and treatment of pulmonary embolism by a foreign body. He underwent lumbar spine surgery for spinal canal stenosis. The surgeons noticed a piece of rubber catheter used to cover a tip of surgical suction was missing during procedures. Lumbar spinal X-ray taken in the operation room revealed the foreign body just anterior to the lumbar spine. The piece of catheter was thought to have migrated in the inferior vena cava through the lumbar vein during blood suction. An enhanced chest multidetector CT (MDCT) taken just after the surgery showed the catheter lodged in the anterior basal branch of the left pulmonary artery (figure 1).

Even though the patient's haemodynamic condition was stable and there were no signs of complete occlusion of the vessel, urgent intervention was indicated considering a risk of secondary complications such as blood clot formation. ${ }^{1}$ The removal was achieved with pulmonary arteriotomy through left lateral thoracotomy (figures 2 and 3). The

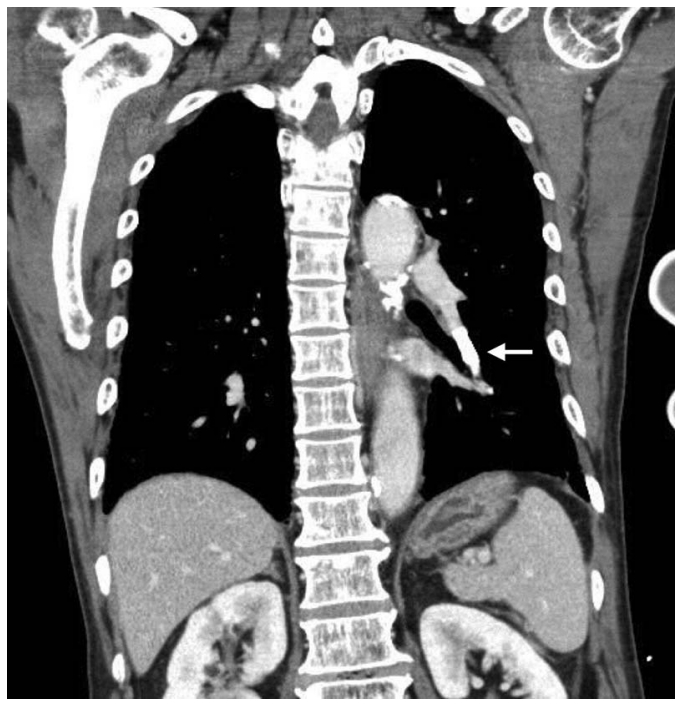

Figure 1 Enhanced chest $\mathrm{CT}$ revealing the catheter lodged in the anterior basal branch of the left pulmonary artery (arrow).

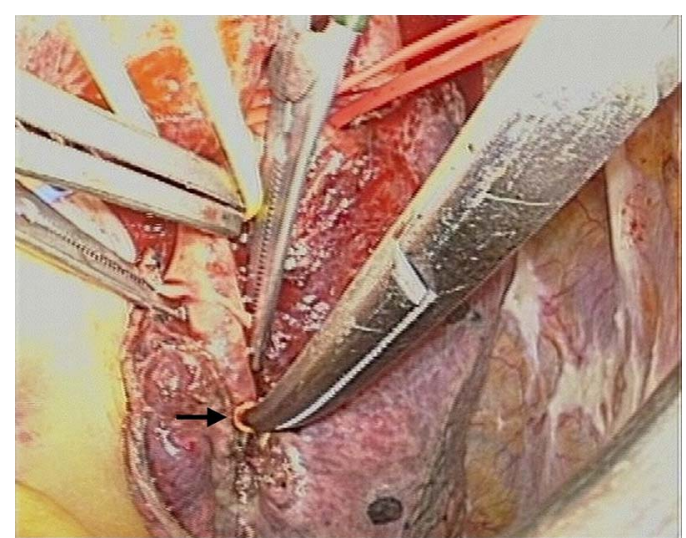

Figure 2 The foreign body (arrow) was retrieved with pulmonary arteriotomy.

postoperative course was uneventful with no evidence of pulmonary artery stenosis or thrombosis.

Foreign body pulmonary embolism can cause clot formation, secondary infection, pulmonary infarction and erosion to a bronchus. ${ }^{12}$ Therefore, removal of foreign bodies should be considered to avoid secondary complications. Although endovascular technique is standard treatment, ${ }^{3}$ we chose the surgical retrieval because the foreign body was firmly stuck and there was no space to bring an

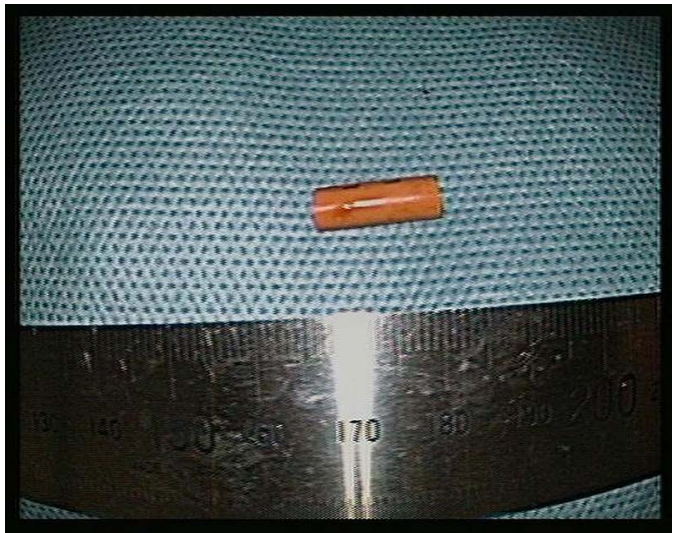

Figure 3 The photo of the retrieved foreign body. 
endovascular snare distally to the foreign body. MDCT was useful to locate the precise anatomy and localisation of the lodged foreign body.

\section{Learning points}

- Although the natural history of foreign body pulmonary embolism is unclear, retrieval of embolus should be considered to prevent secondary complications.

- Percutaneous retrieval of intravascular foreign bodies is standard treatment. If foreign bodies are large or percutaneous retrieval fails, surgical procedures are needed.

- Multidetector CT is useful to locate the accurate localisation of the lodged foreign body.
Contributors NN, MA and AT scrubbed in the operation. MF was the operator of the surgery. All authors managed the patient until the discharge. NN collected the patient date and wrote the paper.

Competing interests None.

Patient consent Obtained.

Provenance and peer review Not commissioned; externally peer reviewed.

\section{REFERENCES}

1 Thanigaraj S, Panneerselvam A, Yanos J. Retrieval of an IV catheter fragment from the pulmonary artery 11 years after embolization. Chest 2000; 117:1209-11.

2 Sarlieve $\mathrm{P}$, Delabrousse $\mathrm{E}$, Rodiere $\mathrm{E}$, et al. Axe fragment pulmonary embolism. Interest of enhanced multislice helical $C T$ with cardiac synchronized acquistions. JBR-BTR 2006;89:12-14.

3 Pelage JP, El Hajjam M, Lagrange C, et al. Pulmonary artery interventions: an overview. Radiographics 2005;25:1653-67.

Copyright 2014 BMJ Publishing Group. All rights reserved. For permission to reuse any of this content visit

http://group.bmj.com/group/rights-licensing/permissions.

BMJ Case Report Fellows may re-use this article for personal use and teaching without any further permission.

Become a Fellow of BMJ Case Reports today and you can:

- Submit as many cases as you like

- Enjoy fast sympathetic peer review and rapid publication of accepted articles

- Access all the published articles

- Re-use any of the published material for personal use and teaching without further permission

For information on Institutional Fellowships contact consortiasales@bmjgroup.com

Visit casereports.bmj.com for more articles like this and to become a Fellow 